\title{
CONTAINER PREFERENCE OF THE ASIAN TIGER MOSQUITO (AEDES ALBOPICTUS) IN KATHMANDU AND LALITPUR DISTRICTS OF NEPAL
}

\author{
I. Gautam¹, A. Kc², R. Tuladhar³, B. D. Pandey4, A. S. Tamrakar², \\ R. Byanju ${ }^{5}$, M. Dhimal ${ }^{6}$, K. Aryal ${ }^{6}$ and U. Kuch ${ }^{7}$
}

\begin{abstract}
In various countries the Asian Tiger Mosquito (Aedes albopictus) is a known vector of dengue and chikungunya viruses and other pathogens, but its ecology and role in disease transmission in Nepal has not been studied yet. Here, we report on an investigation of the seasonal distribution of potential artificial breeding habitats of A. albopictus in urban areas of the Kathmandu and Lalitpur districts of Nepal. Larval collections were performed from April 2009 to March 2010 simultaneously in all the wet containers present in and around the houses of the study areas. Altogether 1873 water containers in Kathmandu district and 1807 in Lalitpur district were searched in 12 months, out of which $107(5.7 \%)$ and 129 (7.1\%), respectively, were found positive for A. albopictus breeding. Within the urban agglomeration of both districts, the breeding was found to vary between localities. Immature stages of A. albopictus were recorded in pre-monsoon, monsoon and post-monsoon seasons as 1.9\%, 6.7\% and 5.6\%, respectively, in wet containers in Kathmandu district. In Lalitpur district, A. albopictus larvae were detected in $4.6 \%, 7.6 \%$ and $7.1 \%$ of the wet containers in the pre-monsoon, monsoon and post-monsoon, respectively. The breeding preference ratio during all seasons was highest for discarded tires lying outdoors in both Kathmandu and Lalitpur districts. Among nine container types searched and examined, 95\% of discarded tires were found positive for A. albopictus larvae and pupae, followed by metal drums (2\%) and plastic drums $(1.25 \%)$. Continued and increased urbanization and vehicle movement in Kathmandu and Lalitpur districts have resulted in increased amounts of non-biodegradable containers such as tires around human dwellings, thereby creating ideal breeding habitats for A. albopictus.
\end{abstract}

Key Words: Aedes albopictus, breeding preference ratio, Nepal, season

\section{INTRODUCTION}

In Nepal, mosquitoes have great public health importance as vectors for the transmission of various diseases including dengue fever (Pandey et al. 2004, 2008). Dengue fever (DF) and its severe manifestations such as Dengue Haemorrhagic Fever (DHF) and Dengue Shock Syndrome (DSS) have emerged as an international public health problem that is now endemic in more than 100 countries. Of the 2.5 billion people who live in dengue endemic countries and are at risk of contracting DF/DHF, 1.3 billion live in 10 countries of the WHO South-East Asia Region that also includes Nepal (WHO 2011). During the past decades, dengue virus which emerged from Southeast Asia gradually became prevalent in Bhutan, India, Maldives, Bangladesh, Pakistan, Indonesia, 
Myanmar, Nepal, Sri Lanka, Thailand and Timor-Leste (WHO 2007). In Nepal, DF cases were for the first time reported from Chitwan in 2004 (Pandey et al. 2004), followed by a report of a suspected dengue fever outbreak in Banke district (Pandey et al. 2008). A first DF case was reported in Kathmandu on 11 September 2006 (WHO 2006) while Sherchand et al. (2001) had earlier reported on the prevalence of dengue virus antibody in southwestern Nepal. All these reports suggest that dengue virus has been circulating in Nepal for several years and is a serious public health threat to the country.

At a global scale, dengue viruses are primarily transmitted by Aedes aegypti and Aedes albopictus mosquitoes. While A. aegypti is considered to be the primary vector of dengue viruses and has repeatedly been incriminated as a driving force in the worldwide emergence of DF, the importance of A. albopictus, e.g., in an endemic rural cycle in Asia, is well recognized (Gubler 1987) and its public health significance well documented (e.g., Russell et al. 1969, Qui et al. 1981, Rosen et al. 1985, Shroyer 1986, Boromisa et al. 1987, Mitchell et al. 1987, Craven et al. 1988, Moore et al. 1988, Francy et al. 1990, Reeves 2000).

The Asian Tiger Mosquito A. albopictus is an aggressive day-biting and globally invasive species whose origins are thought to be in Southeast Asia (Russell et al. 1969). Originally considered a secondary vector of viruses such as dengue virus, A. albopictus was recently demonstrated to be involved in the transmission of chikungunya and dengue viruses in several countries bordering the Indian Ocean, Central Africa and Europe (e.g., see Benedict et al. 2007 and references therein). This species was reportedly also responsible for dengue epidemics in Japan and Taipei during World War II (Hotta 1998).

Females of A. albopictus deposit their eggs in a variety of artificial as well as natural water filled containers (Rattanarikhul and Panthusiri 1994). Human activities associated with settlement, agriculture, urbanization and also climate change have a huge potential for increasing the number, diversity and suitability of larval habitats for this species. Along with the globalization of trade and travel, this has resulted in a dramatic and still ongoing global expansion of the geographic distribution of this species (Benedict et al. 2007), increasing public health concerns about its role as a disease vector. Although there is a rapidly growing body of literature on the ecology of A. albopictus and its breeding site preferences in various countries and different regions (e.g., Chan et al. 1971, Sprenger and Wuithiranyagool 1986, Nasci et al. 1989, Cornel and Hunt 1991, Hobbs et al. 1991, Abdul Kader et al. 1997, Ishak et al. 1997, Moore and Mitchell 1997, Fontenille and Toto 2001, Tsuda and Takagi 2001, Tsuda et al. 2002, Lounibos 2002, Hiriyan et al. 2003, Hiriyan and Tyagi 2004, Regu et al. 2008, Singh et al. 2008, Sumodan 2008, Rao 2010), no such study had been conducted in Nepal where this species is known to have been present in the area of the capital Kathmandu since at least 1969 (Darsie and Pradhan 1990). Here, we report on an entomological survey of A. albopictus larvae and pupae carried out to study the artificial container preference of this species in the urban areas of Kathmandu and Lalitpur districts of Nepal from April 2009 to March 2010. 


\section{MATERIALS AND METHODS}

\section{Study area}

Kathmandu valley is a bowl-shaped valley in central Nepal and lies at a mean elevation of about $1350 \mathrm{~m}$ above sea level. It comprises the three administrative districts with the highest population density in the country, i.e., Kathmandu, Lalitpur and Bhaktapur districts. The valley is surrounded by Bhaktapur district and Kabhrepalanchowk district in the east, Dhading and Nuwakot districts in the west, Sindhupalanchowk and Nuwakot districts in the north, and Makwanpur district in the south.

Kathmandu district is located at $27^{\circ} 42^{\prime} \mathrm{N} 85^{\circ} 20^{\prime} \mathrm{E}$ and covers an area of $395 \mathrm{~km}^{2}$. Similarly, Lalitpur district is situated in the southeastern part of the Kathmandu valley between $27^{\circ} 32^{\prime} 13^{\prime \prime} \mathrm{N}$ and $27^{\circ} 49^{\prime} 10^{\prime \prime} \mathrm{N}$ and $85^{\circ} 11^{\prime} 31^{\prime \prime} \mathrm{E}$ and $85^{\circ} 31^{\prime} 38^{\prime \prime} \mathrm{E}$ and covers an area of $119 \mathrm{~km}^{2}$. As per the latest census of 2011, Kathmandu metropolitan city has the highest population density (20,966 per $\left.\mathrm{km}^{2}\right)$ followed by Lalitpur sub-metropolitan city (14,966 per $\mathrm{km}^{2}$ ) among the urban areas in Nepal. The Kathmandu valley is in the warm temperate zone with a range of monthly maximum temperatures of 19.1-29.1 ${ }^{\circ} \mathrm{C}$, minimum temperatures of $2.4-20.2^{\circ} \mathrm{C}$ and 8.3-263.4 mm precipitation (DHM 2012).

A total of 13 localities within Kathmandu municipal limits (Basundhara, Samakhusi, Gongabu, Balaju, Banasthali, Sitapaila, Kalanki of Kathmandu district and Gwarko, Satdobato, Mahalaxmisthan, Ekantkuna, Nakkhu, Sanepa of Lalitpur district) were surveyed in the premonsoon (March-May), monsoon (June-September), and post-monsoon (October-November) seasons. Larval collections were performed simultaneously in each locality following the single larval technique of WHO (2003) to determine the Aedes breeding status of all the wet containers present in and around the houses and their premises. The number of houses visited in each locality varied depending on the expanse of the area and the types of houses.

\section{Site selection}

Surveys were conducted in urban localities of the ring road area of both districts representing Kathmandu valley. The localities were selected so as to cover a broad representation of various residential areas, automobile workshops, commercial and small industry plots, private junkyards, jetties etc.

\section{Entomological surveys}

To identify the potential breeding habitats of A. albopictus, households in the urban areas of Kathmandu and Lalitpur districts were visited once in each season by an entomological team of two persons between April 2009 and March 2010. Altogether 256 households were visited in the premonsoon, 1023 in the monsoon and 545 in the post-monsoon period. All accessible artificial larval breeding habitats like discarded tires, metal drums, plastic drums, other metal containers, plastic buckets, flower pots, mud pots, cement tanks, and other plastic containers in indoor and outdoor 
locations were inspected using dippers. We did not examine natural habitats such as tree holes, rocks and puddles of water. All trash near and around dwellings (less than $10 \mathrm{~m}$ from the selected house) was also examined. All live larvae and pupae were collected, brought back to the laboratory of the Central Department of Zoology, Tribhuvan University, Kirtipur, Kathmandu, where they were reared until adult emergence. Adult mosquitoes emerged from the reared larvae were identified using the taxonomic keys by Darsie and Pradhan (1990). The container preference of A. albopictus was assessed by calculating the breeding preference ratio (BPR) (Sharma 2002) as presented in the figures and tables.

\section{RESULTS AND DISCUSSION}

In the present study, a total of 3732 wet containers were examined for A. albopictus larvae and pupae and overall $236(6.3 \%)$ of the containers were found positive for these. The highest percentage of positive containers was recorded in the monsoon season $(7.2 \%)$ followed by the postmonsoon (6.4\%). We observed a statistically significant association between the number of A. albopictus positive containers and the total number of wet containers found (Chi-square value $=425.8256, \mathrm{df}=360, \mathrm{P}$-value $=0.009582$ ). This shows that rainfall is an important factor for the breeding of $A$. albopictus in this area of Nepal.

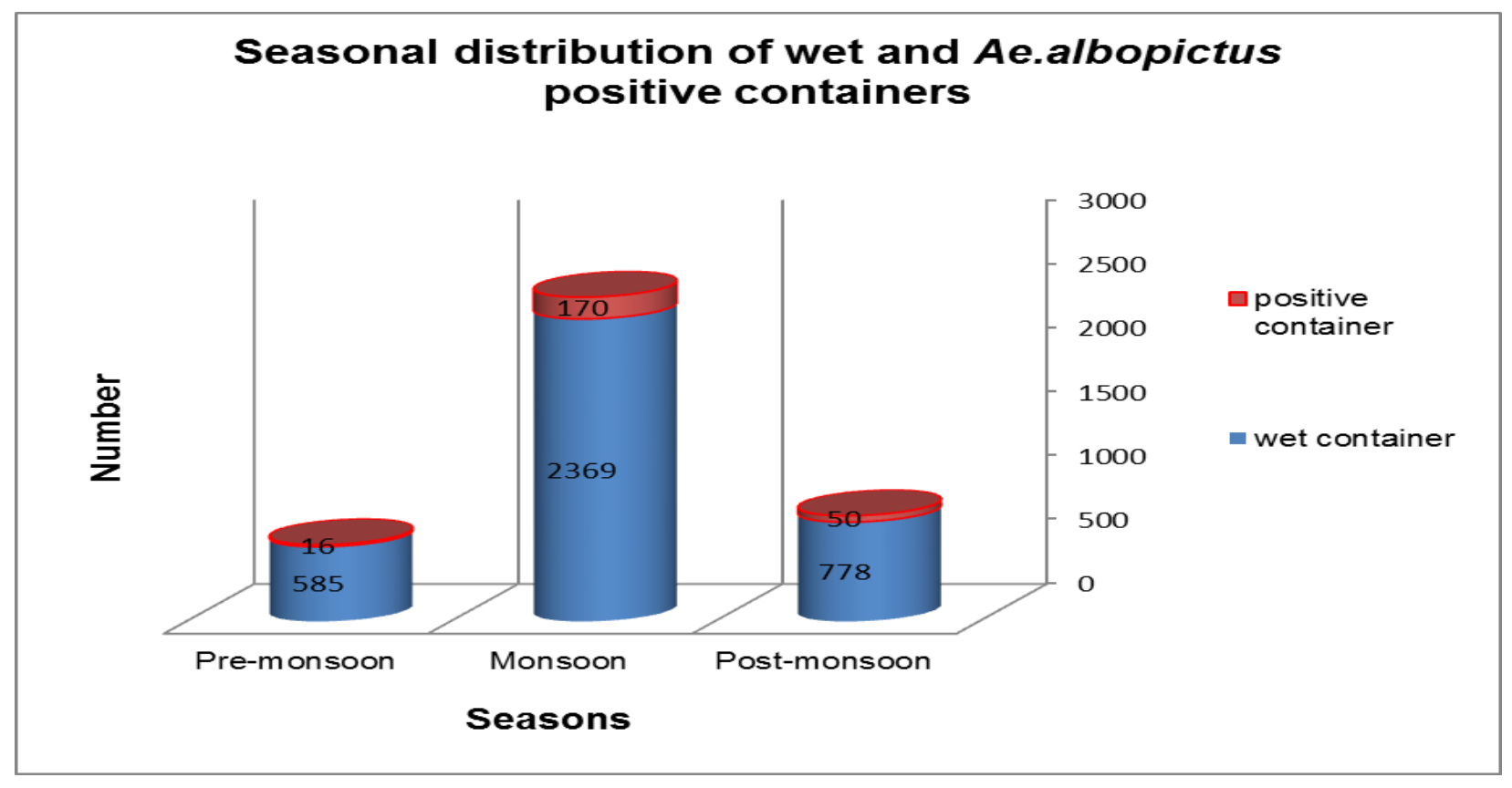

The total number of wet containers examined and the number of containers that were positive for A. albopictus larvae and pupae are presented in Figure 1. Among the nine container types searched and examined, 95\% ( $\mathrm{n}=225)$ of those positive for A. albopictus larvae and pupae were discarded tires, followed by metal drums $(2 \% ; \mathrm{n}=5)$ and plastic drums $(1.25 \%)$. 
In the present study, overall 1873 water containers in Kathmandu district and 1807 in Lalitpur district were searched in three seasons. Out of these, $107(5.7 \%)$ and $129(7.1 \%)$ were found positive for A. albopictus breeding in the respective districts. Details of breeding varied between the localities surveyed within the urban agglomeration of both districts. Immature stages of A. albopictus were recorded in $1.9 \%, 6.7 \%$ and $5.6 \%$ of the wet containers in the pre-monsoon, monsoon and post-monsoon seasons, respectively, in Kathmandu district.

In Lalitpur district, A. albopictus larvae were detected in $4.6 \%, 7.6 \%$ and $7.1 \%$ of the wet containers in the pre-monsoon, monsoon and post-monsoon, respectively. There was no statistically significant association between study districts and A. albopictus positive containers.

Details of the breeding preferences of A. albopictus larvae in Kathmandu and Lalitpur district are provided in Tables 1-6.

\section{Pre-monsoon survey}

In this investigation 316 containers with water were searched in Kathmandu district during the premonsoon period. Of these, 39.9\% were discarded tires followed by metal drums $(32.3 \%)$ and other metal containers (12.7\%). Similarly, in Lalitpur district, of the 217 containers with water searched $31.3 \%$ were metal drums, $28.6 \%$ were discarded tires and $20.3 \%$ were plastic buckets.

Table 1. Breeding preference ratio (BPR) of Aedes albopictus in different artificial breeding habitats in Kathmandu district, Nepal, during the pre-monsoon season.

\begin{tabular}{|c|c|c|c|c|c|}
\hline Type of breeding habitat & $\begin{array}{l}\text { No. of containers } \\
\text { with water }\end{array}$ & $\mathrm{X} \%$ & $\begin{array}{l}\text { No. of containers } \\
\text { with larvae }\end{array}$ & $\mathrm{Y \%}$ & $\begin{array}{l}\text { BPR } \\
(\mathrm{Y} / \mathrm{X})\end{array}$ \\
\hline Discarded Tire & 126 & 39.87 & 6 & 100 & 2.51 \\
\hline Metal Drum & 102 & 32.28 & 0 & 0 & 0 \\
\hline Plastic Drum & 5 & 1.58 & 0 & 0 & 0 \\
\hline Metal Container & 40 & 12.66 & 0 & 0 & 0 \\
\hline Plastic Bucket & 23 & 7.28 & 0 & 0 & 0 \\
\hline Flower Pot & 10 & 3.16 & 0 & 0 & 0 \\
\hline Mud Pot & 8 & 2.53 & 0 & 0 & 0 \\
\hline Cement Tank & 2 & 0.63 & 0 & 0 & 0 \\
\hline Plastic Pot & 0 & 0 & 0 & 0 & 0 \\
\hline Total & 316 & & 6 & & \\
\hline
\end{tabular}


Table 2. Breeding preference ratio (BPR) of Aedes albopictus in different artificial breeding habitats in Lalitpur district, Nepal, during the pre-monsoon season.

\begin{tabular}{|c|c|c|c|c|c|}
\hline Type of breeding habitat & $\begin{array}{l}\text { No. of containers } \\
\text { with water }\end{array}$ & $\mathrm{X} \%$ & $\begin{array}{l}\text { No. of containers } \\
\text { with larvae }\end{array}$ & Y\% & $\begin{array}{l}\text { BPR } \\
(\mathrm{Y} / \mathrm{X})\end{array}$ \\
\hline Discarded Tire & 62 & 28.57 & 6 & 60 & 2.10 \\
\hline Metal Drum & 68 & 31.34 & 3 & 30 & 0.96 \\
\hline Plastic Drum & 20 & 9.22 & 0 & 0 & 0 \\
\hline Metal Container & 0 & 0 & 0 & 0 & 0 \\
\hline Plastic Bucket & 44 & 20.28 & 1 & 10 & 0.49 \\
\hline Flower Pot & 0 & 0 & 0 & 0 & 0 \\
\hline Mud Pot & 13 & 5.99 & 0 & 0 & 0 \\
\hline Cement Tank & 0 & 0 & 0 & 0 & 0 \\
\hline Plastic Pot & 10 & 4.61 & 0 & 0 & 0 \\
\hline Total & 217 & & 10 & & \\
\hline
\end{tabular}

In Kathmandu and Lalitpur districts in the pre-monsoon season, A. albopictus breeding was detected in six water containers (discarded tires) in Kathmandu and ten water containers (six discarded tires, three metal drums and one plastic bucket) in Lalitpur district (Tab. 1+2). We found a statistically significant association between type of container and A. albopictus presence (Chisquare value $=94.186, \mathrm{df}=72$ and $\mathrm{P}$ value $=0.0408)$.

\section{Monsoon survey}

Of the 1217 containers with water surveyed in Kathmandu district in the monsoon season, 54.4\% were discarded tires, $18.7 \%$ were plastic buckets and $9.45 \%$ were metal containers. Altogether 82 water containers (all of them discarded tires) were found positive for A. albopictus in Kathmandu district (Tab. 3).

In Lalitpur district, of the 1152 containers with water surveyed during the monsoon season, $58.85 \%$ were discarded tires followed by plastic buckets (10.5\%) and plastic drums (9.6\%). Eighty-eight water holding containers were positive for A. albopictus in Lalitpur district during the monsoon season (Tab. 4).

Container preference reflected by the breeding preference ratio (BPR) was highest for discarded tires during the monsoon season in Kathmandu district (1.84) and Lalitpur district (1.56) followed by metal containers (0.64) and metal drums (0.62). 
Table 3. Breeding preference ratio (BPR) of Aedes albopictus in different artificial breeding habitats in Kathmandu district, Nepal, during the monsoon season.

\begin{tabular}{|c|c|c|c|c|c|}
\hline Type of breeding habitat & $\begin{array}{l}\text { No. of containers } \\
\text { with water }\end{array}$ & $\mathrm{X} \%$ & $\begin{array}{l}\text { No. of containers } \\
\text { with larvae }\end{array}$ & Y\% & $\begin{array}{l}\text { BPR } \\
(\mathrm{Y} / \mathrm{X})\end{array}$ \\
\hline Discarded Tire & 662 & 54.41 & 82 & 100 & 1.84 \\
\hline Metal Drum & 91 & 7.48 & 0 & 0 & 0 \\
\hline Plastic Drum & 14 & 1.50 & 0 & 0 & 0 \\
\hline Metal Container & 115 & 9.45 & 0 & 0 & 0 \\
\hline Plastic Bucket & 228 & 18.73 & 0 & 0 & 0 \\
\hline Flower Pot & 43 & 3.53 & 0 & 0 & 0 \\
\hline Mud Pot & 50 & 4.11 & 0 & 0 & 0 \\
\hline Cement Tank & 8 & 0.66 & 0 & 0 & 0 \\
\hline Plastic Pot & 6 & 0.49 & 0 & 0 & 0 \\
\hline Total & 1217 & & 82 & & \\
\hline
\end{tabular}

Table 4. Breeding preference ratio (BPR) of Aedes albopictus in different artificial breeding habitats in Lalitpur district, Nepal, during the monsoon season.

\begin{tabular}{llllll}
\hline $\begin{array}{l}\text { Type of breeding } \\
\text { habitat }\end{array}$ & $\begin{array}{l}\text { No. of containers } \\
\text { with water }\end{array}$ & X\% & $\begin{array}{l}\text { No. of containers } \\
\text { with larvae }\end{array}$ & $\begin{array}{l}\text { Y\% } \\
\text { Discarded Tire }\end{array} \quad 678$ & $\begin{array}{l}\text { BPR } \\
(Y / X)\end{array}$ \\
Metal Drum & 106 & 9.85 & 81 & 92.04 & 1.56 \\
Plastic Drum & 111 & 5.64 & 0 & 5.68 & 0.62 \\
Metal Container & 41 & 3.56 & 2 & 0 & 0 \\
Plastic Bucket & 121 & 10.50 & 0 & 2.27 & 0.64 \\
Flower Pot & 11 & 0.95 & 0 & 0 & 0 \\
Mud Pot & 62 & 5.38 & 0 & 0 & 0 \\
Cement Tank & 7 & 0.61 & 0 & 0 & 0 \\
Plastic Pot & 15 & 1.30 & 0 & 0 & 0 \\
Total & 1152 & & 88 & 0 & 0 \\
\hline
\end{tabular}




\section{Post-monsoon survey}

As shown in Table 5, a total of 340 and 438 containers with water were searched in the postmonsoon season in Kathmandu and Lalitpur districts, respectively.

In Kathmandu district, $57.9 \%$ of these were discarded tires, $13.2 \%$ plastic buckets and $9.4 \%$ metal containers. A total of 19 containers (all of them discarded tires) were found positive for A. albopictus larvae and pupae.

Similarly, in Lalitpur district during the post-monsoon $67.1 \%$ of the surveyed containers were discarded tires, $18.0 \%$ metal drums, and $6.4 \%$ plastic drums. Altogether 31 containers (again all of them discarded tires) were positive for A. albopictus larvae and pupae (Tab. 6).

Table 5. Breeding preference ratio (BPR) of Aedes albopictus in different artificial breeding habitats in Kathmandu district, Nepal, during the post-monsoon season.

\begin{tabular}{|c|c|c|c|c|c|}
\hline $\begin{array}{l}\text { Type of breeding } \\
\text { habitat }\end{array}$ & $\begin{array}{l}\text { No. of containers } \\
\text { with water }\end{array}$ & $\mathrm{X} \%$ & $\begin{array}{l}\text { No. of containers } \\
\text { with larvae and } \\
\text { pupae }\end{array}$ & Y\% & $\begin{array}{l}\text { BPR } \\
(\mathrm{Y} / \mathrm{X})\end{array}$ \\
\hline Discarded Tire & 197 & 57.94 & 19 & 100 & 1.73 \\
\hline Metal Drum & 28 & 8.24 & 0 & 0 & 0 \\
\hline Plastic Drum & 9 & 2.65 & 0 & 0 & 0 \\
\hline Metal Container & 32 & 9.41 & 0 & 0 & 0 \\
\hline Plastic Bucket & 45 & 13.24 & 0 & 0 & 0 \\
\hline Flower Pot & 16 & 4.71 & 0 & 0 & 0 \\
\hline Mud Pot & 9 & 2.65 & 0 & 0 & 0 \\
\hline Cement Tank & 4 & 1.18 & 0 & 0 & 0 \\
\hline Plastic Pot & 0 & 0 & 0 & 0 & 0 \\
\hline Total & 340 & & 19 & & \\
\hline
\end{tabular}

Aedes albopictus is known to be able to breed in a wide variety of natural and artificial container habitats. In most published studies this species was commonly found in indoor and outdoor habitats like earthen ware jars, tin cans, ant traps, rubber tires, bowls, drums and tin cans (e.g., Chan et al. 1971), containers used for collecting rubber sap in rubber plantations during the rainy season (Sumodan 2008), shed leaf sheaths of areca nut palms and cocoa pods (Regu et al. 2008, Hiriyan and Tyagi 2004), plastic cups (Hiriyan et al. 1997), coconut shells and plastics dumped around houses (Rao 2010), and drum cans in the hills and mountain areas of Indonesia (Ishak et al. 1997). 
Table 6. Breeding preference ratio (BPR) of Aedes albopictus in different artificial breeding habitats in Lalitpur district, Nepal, during the post-monsoon season.

\begin{tabular}{|c|c|c|c|c|c|}
\hline $\begin{array}{l}\text { Type of breeding } \\
\text { habitat }\end{array}$ & $\begin{array}{l}\text { No. of containers } \\
\text { with water }\end{array}$ & $\mathrm{X} \%$ & $\begin{array}{l}\text { No. of containers } \\
\text { with larvae and } \\
\text { pupae }\end{array}$ & $\mathrm{Y} \%$ & $\begin{array}{l}\text { BPR } \\
(\mathrm{Y} / \mathrm{X})\end{array}$ \\
\hline Discarded Tire & 294 & 67.12 & 31 & 100 & 1.49 \\
\hline Metal Drum & 79 & 18.03 & 0 & 0 & 0 \\
\hline Plastic Drum & 28 & 6.39 & 0 & 0 & 0 \\
\hline Metal Container & 15 & 3.42 & 0 & 0 & 0 \\
\hline Plastic Bucket & 8 & 1.83 & 0 & 0 & 0 \\
\hline Flower Pot & 5 & 1.14 & 0 & 0 & 0 \\
\hline Mud Pot & 6 & 1.37 & 0 & 0 & 0 \\
\hline Cement Tank & 3 & 0.68 & 0 & 0 & 0 \\
\hline Plastic Pot & 0 & 0 & 0 & 0 & 0 \\
\hline Total & 438 & & 31 & & \\
\hline
\end{tabular}

Broken cans and plastic containers were primary breeding sites for A. albopictus during the dry season in Thailand (Chareonviriyaphap et al. 2003). In the present survey, discarded tires lying outdoors were clearly the preferred breeding habitat of A. albopictus. However, larvae were also observed in metal drums and plastic buckets. The unused tires lying outdoors were almost exclusively seen in the urban areas of Kathmandu and Lalitpur districts during this survey. This study highlights that old vehicle tires lying around the households and shops are the major source of A. albopictus breeding in the urban agglomeration of Kathmandu and Lalitpur districts.

From the present entomological survey, it can be concluded that A. albopictus is well-established within the urban areas of Kathmandu and Lalitpur district. Most of the areas had a high frequency of larva-positive discarded tires which are kept outdoors, are rarely eliminated and remain undisturbed most of the time, thus favouring the breeding of A. albopictus mosquitoes.

The availability of such tires in urban areas of these districts is a by-product of increasing vehicle use and traffic. Kathmandu valley has a high density of vehicles, and usually old tires are not disposed of properly due to lack of dumping sites and lack of awareness. Thus, local people have developed a habit of storing and stacking up old tires, sometimes with the hope to re-use or recycle them later. This accumulation of ideal A. albopictus breeding sites that will quickly and effectively hold rain water and rapidly warm up in sunlight even during winter, puts the urban areas of this valley at highest risk. 
In addition, the water supply in the Kathmandu valley is irregular and insufficient due to electric power shortages and water source limitations. As a consequence, almost every household in the valley practices water storage usually with the capacity of the water quantity needed for one to two days. As there is great uncertainty as to when tap water will be available again, water containers such as metal drums and plastic buckets are never emptied. This situation favours the breeding of A. albopictus in metal drums and plastic buckets in the pre-monsoon season, when fewer rain water filled containers are available.

The best conditions for A. albopictus mosquito breeding and the highest numbers of positive containers and mosquito larvae were found during the monsoon followed by the post-monsoon season in both districts. At these times most of the potential habitats/containers of the area were filled with fresh water creating good breeding sites for A. albopictus.

The results of this study highlight the need for an intensification of vector surveillance activities in Kathmandu along with source reduction and public awareness programmes that should specifically be directed at the proper disposal of breeding containers with special attention to discarded tires.

\section{ACKNOWLEDGEMENTS}

Research was financially supported by the Nepal Health Research Council (NHRC) and the research funding programme "LOEWE — Landes-Offensive zur Entwicklung Wissenschaftlichökonomischer Exzellenz" of the Ministry of Higher Education, Research and the Arts of the State

of Hesse, Germany. The authors thank the Head of the Central Department of Zoology, Tribhuvan University, Kritipur, Professor Dr. Ranjana Gupta and Professor Dr. Keshab Shrestha, Chief, Natural History Museum, Tribhuvan University, Swayambhu, for providing the space for this work.

\section{REFERENCES}

Abdul Kader, M.S., P. Kandaswamy, N.C. Appavoo and L. Anuradha, 1997. Outbreak and control of dengue in a village in Dharmapuri, Tamil Nadu. Journal of Communicable Diseases, 29: 69-71.

Benedict, M.Q., R.S. Levine, W.A. Hawley and L.P. Lounibos, 2007. Spread of the tiger: global risk of invasion by the mosquito Aedes albopictus. Vector Borne and Zoonotic Diseases, 7: 76-85.

Boromisa, R.D., K.S. Rai and P.R. Grimstad, 1987. Variation in the vector competence of geographic strains of Aedes albopictus for dengue 1 virus. Journal of the American Mosquito Control Association, 3: 378-386.

Chambers, D.M., L.F. Young and H.S. Hill Jr., 1986. Backyard mosquito larval habitat availability and use as influenced by census tract determined resident income levels. Journal of the American Mosquito Control Association, 2: 539-544.

Chan, K.L., B.C. Ho and Y.C. Chan, 1971. Aedes aegypti (L.) and Aedes albopictus (Skuse) in Singapore City. Bulletin of the World Health Organization, 44 (5): 629-633. 
Chareonviriyaphap, T., A. Pongthep, N. Sommawan and H. Sataporn, 2003. Larval habitats and distribution patterns of Aedes aegypti (Linnaeus) and Aedes albopictus (Skuse) in Thailand. Southeast Asian Journal of Tropical Medicine and Public Health, 34 (3): 529-535.

Cornel, A.J. and R.H. Hunt, 1991. Aedes albopictus in Africa? First records of live specimens in imported tires in Cape Town. Journal of the American Mosquito Control Association, 7: 107-108.

Craven, R.B., D.A. Eliason, D.B. Francy, P. Reiter, E.G. Campos, W.L. Jakob, G.C. Smith, C.J. Bozzi, C.G. Moore, G.O. Maupin and T.P. Monath, 1988. Importation of Aedes albopictus and other exotic mosquito species into the United States in used tires from Asia. Journal of the American Mosquito Control Association, 4: 138-142.

Darsie, R.F. Jr. and S.P. Pradhan, 1990. The mosquitoes of Nepal: Their identification, distribution and biology. Mosquito Systematics, 22: 69-130.

DHM, 2012. The Climate Normal Forms 1981-2010. Kathmandu: Department of Hydrology and Meterology, Government of Nepal. Available from http://www.dhm.gov.np/climate

Fontenille, D. and J.C. Toto, 2001. Aedes (Stegomyia) albopictus (Skuse), a potential new dengue vector in southern Cameroon. Emerging Infectious Diseases, 7: 920-921.

Francy, D.B., C.G. Moore and D.A. Eliason, 1990. Past, present and future of Aedes albopictus in the United States. Journal of the American Mosquito Control Association, 6: 113-114.

Gingrich, J.B., A. Nishalak, J.R. Latendresse, K.J. Sattabong, C.H. Hoke, J. Pomsdhit, K. Chantala, P. Satay, K. Uchieweharnkpt, B.L. Innis, 1992. Japanese encephalitis virus in Bangkok: factors influencing vector infections in three sub-urban communities. Journal of Medical Entomology, 29 (3): 436-444.

Gubler, D.J., 1987. Dengue. In: T.P. Monath (Ed.). The arboviruses: epidemiology and ecology. Volume II. Boca Raton, Florida, USA: CRC Press, pp. 223-260.

Hiriyan, J., S.C. Tewary and B.K. Tyagi, 2003. Aedes albopictus (Skuse) breeding in plastic cups around tea-vendor spots in Ernakulam City, Kerala state, India. Dengue Bulletin, 27: 195-196.

Hiriyan, J. and B.K. Tyagi, 2004. Cocoa pod (Theobroma cacao) potential breeding habitat of Aedes albopictus in dengue sensitive Kerala state, India. Journal of the American Mosquito Control Association, 20 (3): 323-325.

Hobbs, J.H., E.A. Hughes and B.H. Eichold II, 1991. Replacement of Aedes aegypti by Aedes albopictus in Mobile, Alabama. Journal of the American Mosquito Control Association, 7: 488489.

Hotta S., 1998. Dengue vector mosquitoes in Japan: The role of Aedes albopictus and Aedes aegypti in the 1942-1944 dengue epidemics of Japanese main islands. Medical Entomology and Zoology, 49: $267-274$.

Ishak, H., I. Miyagi, T. Toma and K. Kamimura, 1997. Breeding habitats of Aedes aegypti (L.) and Aedes albopictus (Skuse) in villages of Barru, South Sulawesi, Indonesia. Southeast Asian Journal of Tropical Medicine and Public Health, 28 (4): 844-850.

Lounibos, L.P., S. Suárez, Z. Menéndez, N. Nishimura, R.L. Escher, S.M. O’Connell and J.R. Rey, 2002. Does temperature affect the outcome of larval competition between Aedes aegypti and Aedes albopictus? Journal of Vector Ecology, 27 (1): 86-95. 
Mitchell, C.J., B.R. Miller and D.J. Gubler, 1987. Vector competence of Aedes albopictus from Houston, Texas, for dengue serotypes 1 to 4, yellow fever and Ross river viruses. Journal of the American Mosquito Control Association, 3: 460-465.

Moore, C.G., D.B. Francy, D.A. Eliason and T.P. Monath, 1988. Aedes albopictus in the United States: rapid spread of a potential disease vector. Journal of the American Mosquito Control Association, 4: 356-361.

Moore, C.G. and C.J. Mitchell, 1997. Aedes albopictus in the United States: ten-year presence and public health implications. Emerging Infectious Diseases, 3: 329-334.

Nasci, R.S., C.G. Hare and F.S. Willis, 1989. Interspecific mating between Louisiana strains of Aedes albopictus and Aedes aegypti in the field and the laboratory. Journal of the American Mosquito Control Association, 5: 416-421.

Pandey, B.D., S.K. Rai, K. Morita and I. Kurane, 2004. First case of dengue in Nepal. Nepal Medical College Journal, 6: 157-159.

Pandey, B.D., K. Morita, S.R. Khanal, T. Takasaki, I. Miyazaki, T. Ogawa, S. Inoue and I. Kurane, 2008. Dengue virus, Nepal. Emerging Infectious Diseases, 14 (3): 514-515.

Qui, F., H. Zhang, L. Shao, X. Li, H. Luo and Y. Yu, 1981. Studies on the rapid detection of dengue virus antigen by immunofluorescence and radioimmunoassay. Chinese Medical Journal, 94: $653-658$.

Rao, B.B., 2010. Larval habitats of Aedes albopictus (Skuse) in rural areas of Calicut, Kerala, India. Journal of Vector Borne Diseases, 47: 175-177.

Rattanarithikul, R. and P. Panthusiri, 1994. Illustrated keys to the medically important mosquitoes of Thailand. Southeast Asian Journal of Tropical Medicine and Public Health, 25 (1): 1-66.

Reeves, W.C., 2000. The threat of exotic virus introductions into California. Proceedings of the Mosquito and Vector Control Association of California, 68: 9-10.

Regu, K., R. Rajendran, M. Tamilselvan and C.T. Ganesh, 2008. Shed leaf sheaths of areca nut palm as a major breeding source of Ae. albopictus Skuse (Diptera: Culicidae) in Kerala. Hexapoda, 15: $111-113$.

Rosen, L., L.E. Rozenboom, D.J. Gubler, J.C. Lien and B.N. Chaniotis, 1985. Comparative susceptibility of mosquito species and strains to oral and parental infection with dengue and Japanese encephalitis viruses. American Journal of Tropical Medicine and Hygiene, 34: 603-615.

Russell, P.K., D.J. Gould, T.M. Yuill, A. Nisalak and P.E. Winter, 1969. Recovery of dengue-4 viruses from mosquito vectors and patients during an epidemic of dengue haemorrhagic fever. American Journal of Tropical Medicine and Hygiene, 18: 580-583.

Sharma, R.C., 2002. Breeding habitats and larval indices of Aedes aegypti (L.) in residential areas of Rajahmundry town, Andhra Pradesh. Journal of Communicable Diseases, 34: 50-58.

Sherchand, J.B., B.D. Pandey, K. Haruki and M. Jimba, 2001. Sero-diagnosis of Japanese encephalitis and dengue virus infection from clinically suspected patients of Nepal. Journal of Institute of Medicine, 23: 25-31.

Shroyer, D.A., 1986. Aedes albopictus and arboviruses: a concise review of the literature. Journal of the American Mosquito Control Association, 2: 424-428. 
Singh, R.K., M.K. Das, R.C. Dhiman, P.K. Mittal and A.T.S. Sinha, 2008. Preliminary investigation of dengue vectors in Ranchi, India. Journal of Vector Borne Diseases, 45: 170-173.

Sprenger, D., T. Wulthiranyagool, 1986. The discovery and distribution of Aedes albopictus in Harris County, Texas. Journal of the American Mosquito Control Association, 2: 217-219.

Sumodan, PK., 2008. Potential of rubber plantations as breeding source for Ae. albopictus in Kerala, India. Dengue Bulletin, 27: 197-8.

Tsuda, Y., J. Kabayashi, S. Nambanya, I.M. Miyagi., T. Toma, S. Pompida and K. Manivang, 2002. An ecological survey of dengue vector mosquito in central Lao PDR. Southeast Asian Journal of Tropical Medicine and Public Health, 33 (1): 63-67.

Tsuda, Y. and M. Takagi, 2001. Survival and development of Aedes aegypti and Ae. albopictus (Diptera: Culicidae) larvae under a seasonally changing environment in Nagasaki, Japan. Environmental Entomology, 30: 855-860.

WHO, 2002. Dengue and dengue haemorrhagic fever. Fact sheet no. 117. Available online from http://www.who.int.mediacenter/factsheets/fs 117/

WHO, 2003. Guidelines for dengue surveillance and mosquito control, 2nd Ed. Manila, Philippines: WHO Regional Office of the Western Pacific, 105 pp.

WHO, 2006. Outbreak investigation of DF in Nepal, SEARO. Available online from http://WWW.searo.who.int/LinkFiles/Dengue_dengue_Nepal.pdf

WHO, 2007. Trend of dengue cases and CFR in SEARO countries. Nepal. The South East Asia and Western Pacific Region: World Health Organization. Available online at: http://www.searo.who.int/EN/Section10/Section332/Section2277_13402.htm

WHO, 2011. Comprehensive guidelines for the prevention and control of dengue and dengue haemorrhagic fever: SEARO. Available online from http://www.searo.who.int/en/ Section10/Section332/Section554.htm

\section{Authors' Addresses:}

\section{Ishan Gautam}

Natural History Museum, Tribhuvan University, Swayambhu, Kathmandu, Nepal. (email: is_gautam@rediffmail.com)

\section{Aradhana Kc and Anand Shova Tamrakar}

Central Department of Zoology, Tribhuvan University, Kirtipur, Kathmandu, Nepal.

Reshma Tuladhar

Central Department of Microbiology, Tribhuvan University, Kirtipur, Kathmandu, Nepal.

\section{Basu Dev Pandey}

Everest International Clinic and Research Center, Kathmandu, Nepal.

\section{Reena Byanju}

Patan Multiple Campus, Tribhuvan University, Lalitpur, Nepal.

Meghnath Dhimal and Krishna Aryal

Nepal Health Research Council, Ramshahpath, Kathmandu, Nepal.

\section{Ulrich Kuch}

Biodiversity and Climate Research Centre (BiK-F), Frankfurt am Main, Germany. 